\title{
MODALITY, REFERENCE AND SPEECH ACTS IN THE PSALMS ${ }^{1}$
}

\author{
Andy Warren
}

This study takes the results of linguistic and form-critical work on the biblical Psalms, together with some of the findings of comparative linguistics in the fields of modality and speech acts, to look at forms of reference and modality in the Psalms, focussing particularly on Interrogative, Negative, and Imperative sentencetypes. Amongst the most significant results are a full reanalysis of the Hebrew verbal system, primarily in terms of modality (Table 2), and a more systematic distinction between different types of cohortatives (Table 1) and jussives.

The Introduction (ch. 1) firstly surveys the work which has already been done on the distinctive lexis (Tsevat), morphology, and syntax (Sappan) of the Psalter, as well as work in sociolinguistics (Finley, Wilt), formulaic language (Culley), and form-criticism (Gunkel, Westermann, Aejmelaeus, etc.). Then an overview is given of some of the categories and terminology standardly used in some fields of comparative linguistic semantics and pragmatics (Lyons, Levinson), including communication theory, speech-act theory (Austin, Searle) and the study of modality (Palmer). Structuralist method in the study of Biblical Hebrew (Collins, Prinsloo) is considered, as are some of the recent studies of Biblical Hebrew Narrative syntax (Richter, Talstra; Schneider, Niccacci; Andersen, Longacre), as the background to the present treatment of Discourse. The approach taken here is that

discourse functions [of individual verbal forms] are secondary, contextual applications of a more basic temporal, aspectual or modal function. Discourse functions are not inherent to the verbal form, but to the clauses within which the verbal form is incorporated. ${ }^{2}$

1 Andy Warren, Modality, Reference and Speech Acts in the Psalms (unpublished Ph.D. thesis, Faculty of Oriental Studies, Cambridge University, 1998); supervisors: Prof. J.A. Emerton, Prof. R.P. Gordon, and Dr G.A. Khan.

2 Jan Joosten, handout at conference Narrative Syntax and the Hebrew Bible, Tilburg, 1996. 
Reference (ch. 2) considers two distinct features. The first is the pragmatic function of exophoric 'reference' to real-world context, particularly in terms of participant reference, the use of the three grammatical persons to refer to the three rhetorical persons (or 'actants' - the Psalmist, the enemy, and God) and the difference between reference by name, description, pronoun, and verbal morphology. The second is the syntactic function of endophoric 'relation' to linguistic cotext; this covers all kinds of deixis, nominal and adverbial, and requires a discussion of pronoun topicalisation and its most frequent function, adversativity (as in $w a^{2 a} n \hat{\imath}$ ).

Mood (ch. 3) considers the cross-linguistic feature properly termed 'modality', which may be described as the grammatical reflex of assertivity or reality. Modal forms dominate the language of the Psalter. A language may give modality grammatical realisation in distinct moods, and this is shown to be the case in Biblical Hebrew, which has three moods: a Deontic (or 'volitional') mood [+MOD, $+\mathrm{VOL}]$ based on short-form yiqtōl, an Epistemic (or subjunctive) mood [+MOD, -VOL] based on long-form yiqtōl, and an Indicative mood [-MOD] based on the Anterior $q \bar{a} t a l$ form supplemented by the predicative participle (developing Joosten, Niccacci). The formal systems are labelled D-system, E-system, and I-system respectively, and the schema is developed into a comprehensive account of how Biblical Hebrew verbal forms and functions relate (see Table 2). Apparent exceptions are explained as either secondary, natural extensions of the primary functions as given (e.g. yiqtōl for present potentialis will [tend to], past iterative 'would [usually]' and past prospective 'was about to') or form-function 'skewing' (e.g. precative perfect 'Oh, that you would' and preceptive imperfect 'You will!'). Features closely related to modality are considered, such as embedding and vocative, as well as the question of the scope of Interrogative, Negative, and Imperative force.

Interrogative (ch. 4) looks at the various basic morphemes involved in pronominal, adverbial, and clausal interrogation. Exclamatory and desiderative functions are identified, as well as relationships to subordination, Negation, and conditionality.

Negative (ch. 5) looks at the various types of Negation available in Biblical Hebrew for individual arguments, nominal clauses, infinitives, non-Deontic verbal clauses and Deontic verbal clauses. The functional distinction between $l \bar{o}$ ' and ' $a l$ is given particular consideration. Some of the rhetorical functions of Negation are described. 
Imperative (ch. 6) considers not only the verbal form $q^{e} t$ tol (the 'imperative'), but the entire Deontic class, centred on short-form $y i q t o \bar{l}$-x ('jussive'), and also including 'eqt le lâ ('cohortative'). The chapter begins by considering the particle $-n \bar{a}$ ' and the Deontic use of modal verbs, then looks in turn at the imperative, cohortative, and jussive in terms of argument structure and illocutionary force (also Speaker and Addressee-see Table 1), and ends by looking at Deontic uses of nominal clauses.

The Conclusion (ch. 7) brings together the results of the preceding chapters, showing how these various features relate to each other on the grammatical level, and how they contribute to the dynamic and texture of a psalm on the rhetorical level. Some suggestions are made as to how the method and results of this work might illuminate other biblical texts. ${ }^{3}$

Table 1: Functions of Main-Clause Cohortatives

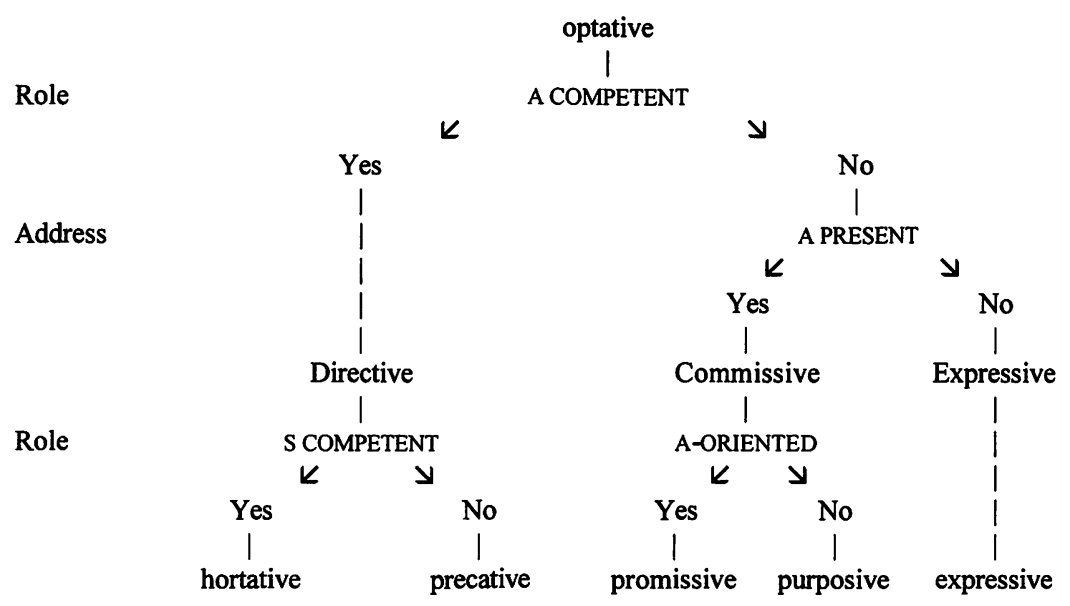

3 For applications of this work to texts outside the Psalms, see A. Warren, 'Did Moses permit Divorce? Modal weqatal as Key to New Testament Readings of Deuteronomy 24:1-4', TynB 49.1 (1998) 39-56, and W.Th. van Peursen, The Verbal System in the Hebrew Text of Ben Sira (privately published, 1999). 


\section{Table 2: A Reanalysis of the Hebrew Verbal System}

1. Primary Functions MOOD

Mood:

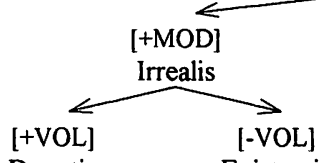

Modal System: Deontic

Relative Tense:

Deontic

(Eur. equiv's: optative

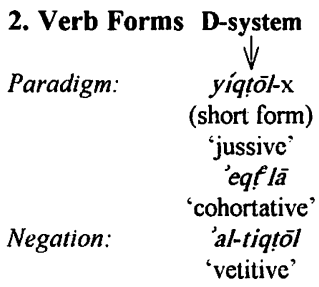

Continuation:

Person-unmarked: $q^{i} t o ̄ l$ 'imperative' qot lā 'adhortative'

\section{Secondary Functions}

4. 'Skewing' 'precative perf.' 'preceptive impf.' lö tiqtōl 'prohibitive'

Conditional:

Sequential:
Epistemic

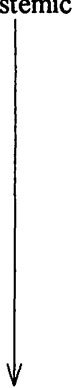

Epistemic subjunctive

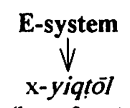

(long form)

'imperfective' ( \pm nun paragogicum)

$$
\text { lós tiqtol }
$$

$$
\text { W'qātal }
$$

'perf. consec.' qạtōl

'infinitive absolute'

$$
\text { 'infinitive absolute' }
$$

\section{pres. potentialis}

past iterative past prospective

Neg, Int, Cond

'prophetic perf.'

Epistemic yíqtol-x

$$
\begin{gathered}
\text { 'im qātal } \\
\text { ki qātal } \\
\text { w' qātal }
\end{gathered}
$$
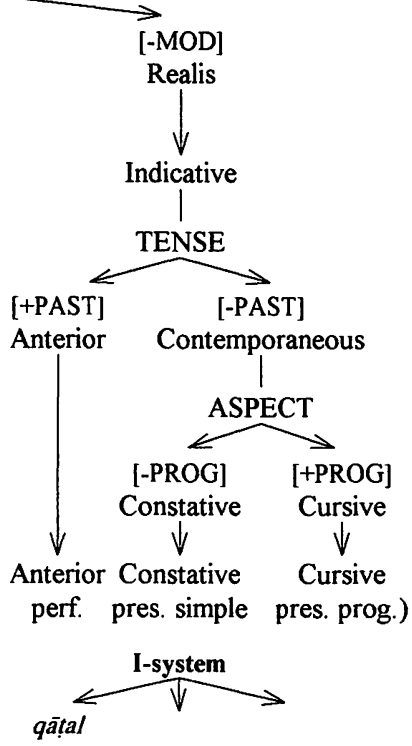

'perfective'

$$
\text { lō' qãtal 'ên qợtel }
$$

wayyíqtōl

'impf. consec.'

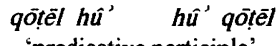
'predicative participle' 'classifying' 'identifying'

\section{Performative}

Epistolary

5. Rel. Modality irrealis 